ployees be hired to teach lower division courses. At many institutions, faculty are misappropriated such that, as student preferences change, one school within an institution may have a disproportionately large number of full-time, tenure-track scholars and another with many more students may have too few faculty.

Both administrators and tenure track faculty do, it seems, have some control over the use of part timers, including how those nontenure-track faculty are treated. Conferees who had been part-time teachers, recounted experiences of being considered second-class citizens, virtually ignored by the full-time faculty.

Various papers made it clear that the disciplines varied in the degree to which part-time faculty are used and in the apparent need for such contingent workers. A major drawback of having a large group of such employees is that students can go through four or five years of college and can have taken few courses from the regular faculty, have no ongoing relationships with them, and have no one who knows their work sufficiently to write a knowledgeable letter of recommendation on their behalf.

Research presented by a variety of scholars pointed to some important facts concerning the use of part-time and nontenure-track faculty, including the following:

-About one-half of part-time faculty prefer to work part-time, while the other half would like full-time, tenure-track positions but can not find them.

-The proportion of part-time faculty at all postsecondary, academic institutions has increased from $22 \%$ in 1970 to more than $40 \%$ in 1993.

-The greatest use of part-time faculty is in community colleges. The proportion of faculty in community colleges increased from $19 \%$ in 1970 to $32 \%$ in 1993 , and $64 \%$ of community college faculty hold part-time appointments.

-Part-time employees are less likely to hold doctoral degrees.

-Part-time faculty report spending substantially less time on class preparation and out-of-class interaction with students and are less likely to publish than full-time faculty.

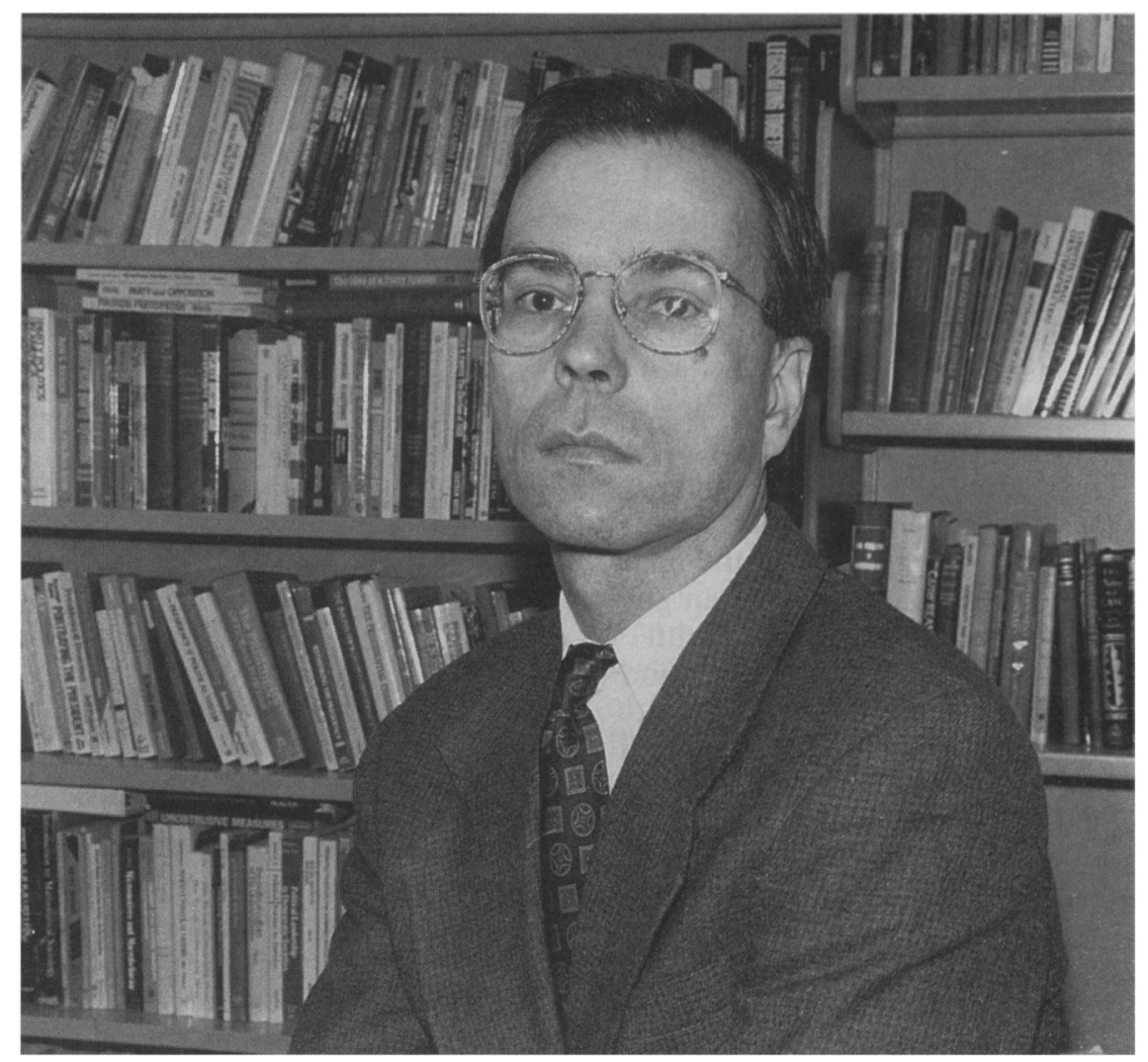

Gregory A. Calderia

- Part-time faculty receive much lower pay, fewer benefits, and less institutional support (such as offices and computer access) than their full time counterparts.

- Among Ph.D. faculty at Ph.D. granting institutions, the proportion of tenure-track faculty has declined from $85 \%$ in 1981 to $75 \%$ in 1975.

-Among Ph.D. faculty at M.A. granting institutions, the proportion of tenure-track faculty has declined from $90 \%$ in 1981 to $87 \%$ in 1995.

-One study of community colleges estimated that a teaching load which would require $\$ 35,000$ to $\$ 40,000$ for a full-time appointment would cost only $\$ 15,000$ if taught by several part-time faculty.

On the last day of the meeting, the conferees agreed on a draft statement that will be edited by a drafting committee and distributed to scholarly societies for further consideration. The report will be published in a future issue of $P S$ and will be presented to APSA's Council for possible action.

\section{Calderia Named AJPS Editor}

Gregory A. Calderia, professor of political science at Ohio State University will assume duties as Editor of the American Journal of Political Science on January 1, 1998. Midwest Political Science Association President Arlene Saxonhouse, University of Michigan, made the announcement at the Midwest annual meeting in April. Calderia replaces Kenneth Meier of the University of Wisconsin, Milwaukee, who has held the position since 1994. Calderia's appointment will run through 2001 . Beginning on January 1, manuscripts for the AJPS should be sent to: Gregory Calderia, American Joumal of Political Science, Department of Political Science, Ohio State University, 2140 N. Derby Hall, 154 North Oval Mall, Columbus, OH 43210. 


\section{APSA BALLOT'98

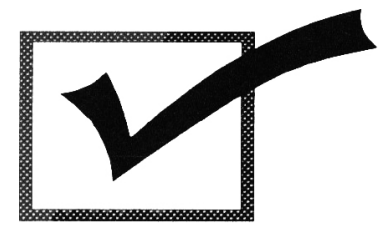

\section{CALL FOR NOMINATIONS \\ APSA OFFICERS AND COUNCIL}

The APSA Nominations Committee welcomes your suggestions for candidates for available Council seats and offices. This year, eight Council seats, three vice-presidencies, and the offices of president-elect and association secretary are open. Council members serve staggered two-year terms. Vice presidents serve one-year terms, as do the president-elect and secretary.

Please return your list of nominees to APSA by February 16, 1998. You may nominate up to three people for the Council, but only one person each for president-elect, vice president, and secretary.

The Nominations Committee will meet in late February to begin compiling a slate of candidates, which they will present to the current Association president no later than April 15, 1998. Elections will be held during the Business Meeting at the 1998 APSA Annual Meeting to be held in Boston, September 3-6.

\section{APSA Council}

\section{Name}

Address

City, State Zip

Phone/Email Vita Attached

\section{Name}

Address

City, State Zip

Phone/Email
Vita Attached

\begin{tabular}{l}
\hline Name \\
\hline Address \\
\hline City, State Zip \\
\hline Phone/Email \\
President-Elect \\
\hline Name \\
\hline Address \\
\hline City, State Zip \\
\hline Phone/Email
\end{tabular}

